\title{
シールドトンネルのひび割れ 進展過程に関する一考察
}

\author{
焼田 真司 1 - 仲山 貴司 2 - 小西 真治 3 ・赤木 寛一 4 \\ ${ }^{1}$ 正会員 （公財）鉄道総合技術研究所 構造物技術研究部（下185-8540 東京都国分寺市光町2-8-38） \\ E-mail: yakita@rtri.or.jp \\ 2正会員 （公財）鉄道総合技術研究所 構造物技術研究部（广185-8540 東京都国分寺市光町2-8-38） \\ E-mail: nakayama@rtri.or.jp \\ 3 正会員 工博 （公財）鉄道総合技術研究所 事業推進室（广185-8540 東京都国分寺市光町2-8-38） \\ E-mail: konishi@rtri.or.jp \\ 4フェロー会員 工博 早稲田大学理工学術院教授 創造理工学部 \\ （干169-8555 東京都新宿区大久保3-4-1） \\ E-mail: akagi@waseda.jp
}

\begin{abstract}
軟弱な粘性土地盤中に建設されたシールドトンネルには, 長期的な圧密作用で内空変位やひび割れ・継 手目開きが生じる場合があることが知られている．しかし，多岐の要因で生じるひび割れ・継手目開きか ら, 圧密に起因するものを特定することは困難であることから, トンネルが経験した環境履歴に応じたひ び割れ・継手目開きの進展過程を再現する計算法が必要である．そこで本研究では，実トンネルのシミュ レーションを通して，このようなひび割れ・継手目開きを再現できる数值解析法を提案する.
\end{abstract}

Key Words : shield tunnel, soft clayey ground, crack propagation, finite element analysis

\section{1. はじめに}

\section{(1) 研究目的}

鉄道トンネルの維持管理においても性能規定化が進行 し ${ }^{1)}$ ，使用性や耐久性に対する関心が高まるなか，既設 シールドトンネルには多岐にわたる要因で様々な変状が 顕在化しつつある.このうち, 軟弱な粘性土地盤中に建 設されたシールドトンネルには，掘削による応力解放や 地下水位の変動, 地上部の利用状況の変化等による圧密 に起因して，内空変位やひび割れ・継手目開きが発生す る場合があることが知られている2へ５．この際，補修， 補強の意思決定を行うため, 過去に応力の残存余裕を算 定する等, 許容応力を中心とした研究が数多く実施され てきた. しかし，一方で，多岐の要因で生じるセグメン トのひび割れ・継手目開きから，圧密に起因するものを 特定することは困難であることから，ひび割れ・継手目 開きを再現する計算法の確立が望まれている.

そこで, 本論文では，シールドトンネルが経験した環 境履歴を入力して現在に至るまでのひび割れ・継手目開 きを再現できる数值解析法 (以下, 再現解析法) を構築 し, 中子形セグメントを使用した実トンネルのシミュレ ーションを通して, その適用性を検証した.

\section{(2) 既往の研究}

許容応力度に対する残存余裕を算定する計算法に関す る既往研究では, 主に, 従来の設計計算法を軸に圧密に よる付加荷重を作用させる手法を採用している. 例えば 旧国鉄の技術指針のにンンネルと地盤の剛性の違いによ る設計上の扱い方が示されている.これは埋設管に作用 する鉛直荷重算定の基礎理論とされる Marston ${ }^{7}$, Spangler ${ }^{8}$ の方法に基づき鈆直荷重を定めるものである. また, 小山ら ${ }^{9}$ は地下水位低下に伴う地盤の有効応力解 析による付加荷重の算定法を検討し提案している. さら に, 斉藤ら゙は建設から10年程度経過したトンネルの内 空変位量から「はりーばねモデル」で付加荷重を逆算す る手法を提案している.

周辺地盤の変形量を算定する計算法を提案する既往研 究としては, 例えば, 赤木ら ${ }^{10), 11)}$ は縮小模型実験を行 い, トンネル周辺地盤の変形と土圧の変化を経時的に調 查し, トンネル周面の排水条件の違いによるトンネル作 用土圧の経時変化を示した. 有泉ら ${ }^{3)}$ はトンネル自体か らの排水においても長期荷重変動が発生しうることを遠 心模型実験から確認し, トンネルの存在により地盤の変 形が抑制され地盤内応力が再配分されることで長期荷重 変化が発生していることを報告している．また，その害 験結果について土水連成解析によるフィッティングで妥 
当性を確認し, 各種条件に関するパラメータスタディで トンネルに作用する長期荷重の影響度合いを考察してい $ろ^{12)}$.

\section{（3）再現解析法}

本研究における再現解析法とは，まず，当該トンネル が経験した環境履歴を入力する「土水連成解析」からト ンネル全周の内空変位分布を求め, つぎに，構造部材の 形状，非線形挙動を精緻に表現する三次元有限要素解析 手法 ${ }^{13)}$ （以下，「非線形FEM」）をシールドトンネル に適用し，「土水連成解析」で求めたトンネル全周の内 空変位分布の鉛直成分を入力値として，ひび割れ・継手 目開きの進展過程を求めるものである（図-1）.

ただし，既往研究の多くは，セグメントを弾性体とし て仮定しているため，圧密による影響は “荷重”として 取り扱っているが，非線形FEMでは，コンクリートの変 位量に対する荷重増分が小さい荷重-変位領域を取扱う ため，これを“変位”として入力する必要がある(図-2).

\section{2. 対象トンネル}

\section{(1) トンネル諸元}

シミュレーションの対象としたシールドトンネルは, 沖積粘性土層に位置するものであり，その地質縦断図を 図-3に示す，上部に埋土層と沖積砂質土層があり，その 下に軟弱な沖積粘性土層が層厚20〜30mで堆積している。 地盤の主な物性值は表-1の通りであるが，透水係数は実 測值がないため，一般的な沖積砂層，粘性土層での推定 値を使用した．また，ポアソン比についてはFc，Yu-s層 は一般的な值を使用し，Yl-c，Na-si層はヤーキーの式か ら設定した.

トンネルは泥水式シールド工法で施工され，外径が 6900mm，土被りは13.0〜26.5m，シールド掘進の延長が 約1.47kmで1985年に掘進を開始し1987年に竣工している。 セグメントは主に高さ $480 \mathrm{~mm}$, 幅 $1 \mathrm{~m}$ の中子形のRCセグ メントを使用している. セグメントの主な物性值は表-2 の通りである.

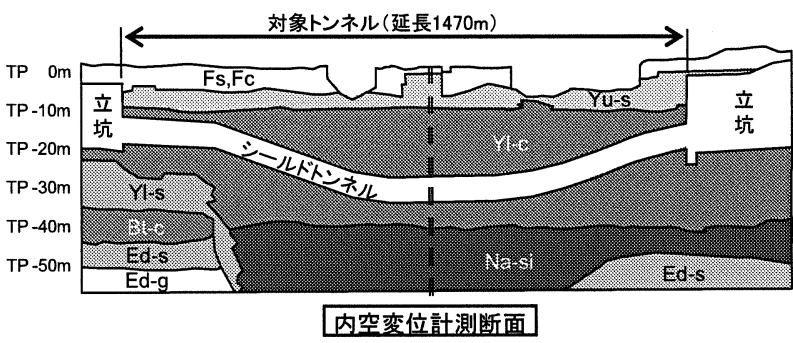

図-3 地質縦断図

表-1＼cjkstart地盤の物性值

\begin{tabular}{|c|c|c|c|c|}
\hline & $\mathrm{Fc}$ & $\mathrm{Yu}-\mathrm{s}$ & $\mathrm{Yl}-\mathrm{c}$ & $\mathrm{Na}-\mathrm{si}$ \\
\hline 弾性係数 $\left(\mathrm{kN} / \mathrm{m}^{2}\right)$ & 2500 & 25250 & 4498 & 38300 \\
\hline 湿潤密度 $\left(\mathrm{g} / \mathrm{cm}^{3}\right)$ & 1.73 & 1.84 & 1.63 & 1.83 \\
\hline ポアソン比 & 0.35 & 0.35 & $0.27^{※ 2}$ & $0.43^{* 2}$ \\
\hline 透水係数 $(\mathrm{m} / \mathrm{s})^{* 1}$ & $1.0 \times 10^{-7}$ & $1.0 \times 10^{-5}$ & $1.0 \times 10^{-8}$ & $2.0 \times 10^{-8}$ \\
\hline
\end{tabular}

$※ 1$ : 推定値 $※ 2 \quad \nu=\mathrm{K}_{0} /\left(1+\mathrm{K}_{0}\right)=0.27 \quad \mathrm{~K}_{0}=1-\sin \phi$ $\phi=38.6^{\circ}$ (Yl-c), $\phi=14.2^{\circ}$ (Na-si) えると地般がトンネルを引張り 実現象と異なるため鉛直変位 のみ使用する)

図-1＼cjkstart再現解析法の流れ

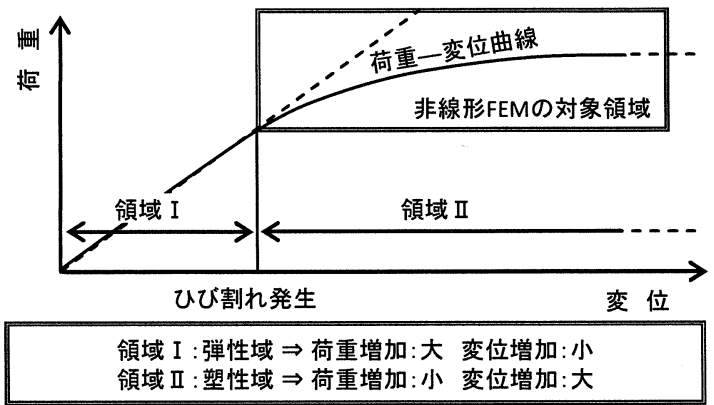

図-2 コンクリートの荷重変位曲線の模式図 


\section{（2）環境履歴と変状}

対象トンネルが経験した環境履歴として把握されてい る事項には，(1)シールド掘削による影響と(2)地下水位が 竣工後の 18 年間で約 $5 \mathrm{~m}$ 上昇したことによる影響（付近 に設置された観測井での測定結果 ${ }^{14)}{ }^{15)}$ ） が挙げられる。

一方，変状としては，竣工後から定期的に計測された 内空変位量から, トンネルは鉛直方向に縮小し, 水平方 向に拡大する横つぶれ傾向にあることが確認されている. このうち，図-3中の「内空変位計測断面」位置における クラウンーインバート間の鉛直内空変位とスプリングラ インの水平内空変位の計測結果を図-4に示す.

この計測断面では計測開始直後から約3年は鉛直，水 平方向ともに $1 \mathrm{~mm} /$ 年程度の内空変位が進行していたが, 経年とともに内空変位の進行は緩やかになり, 計測開始 から約7年目以降はほぼ安定している。.また，建設当初 にひび割れは確認されていなかったが，20年後には図-5 に示すように, クラウン付近の主桁部軸方向に微細なひ び割れが分散して発生していることが確認されている. ただし，ひび割れの発生時期は特定されていない.

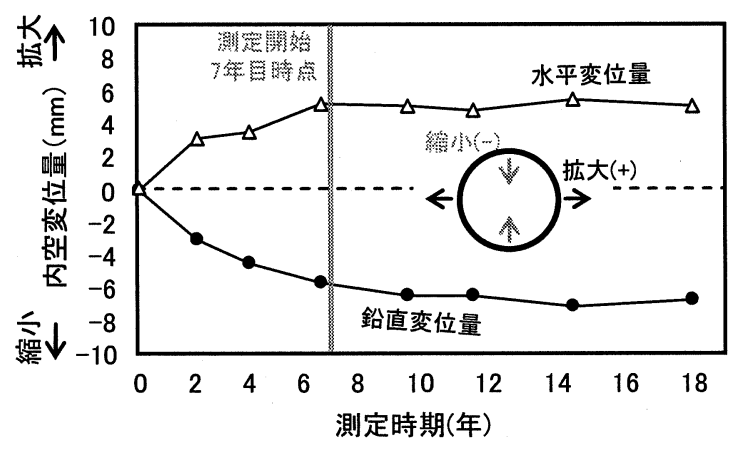

図-4 内空変位の経年変化

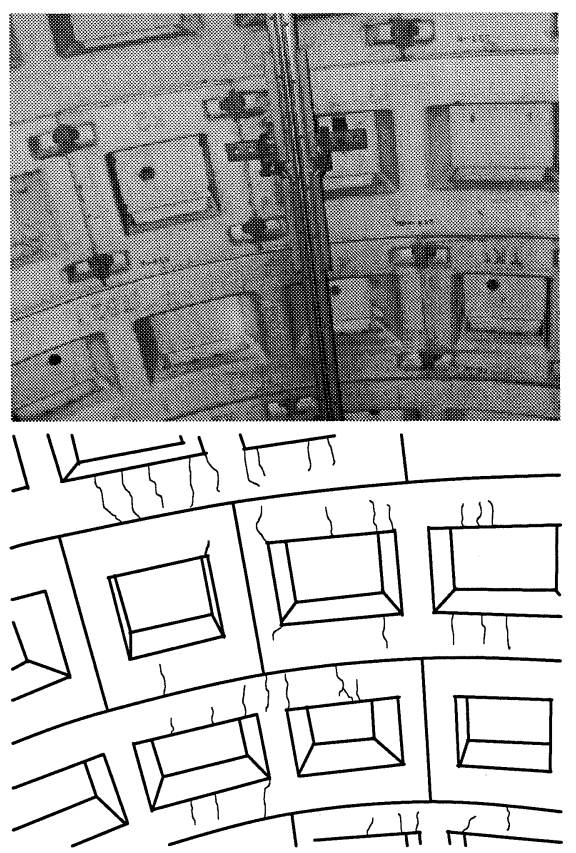

図-5 ひび割れ発生状況

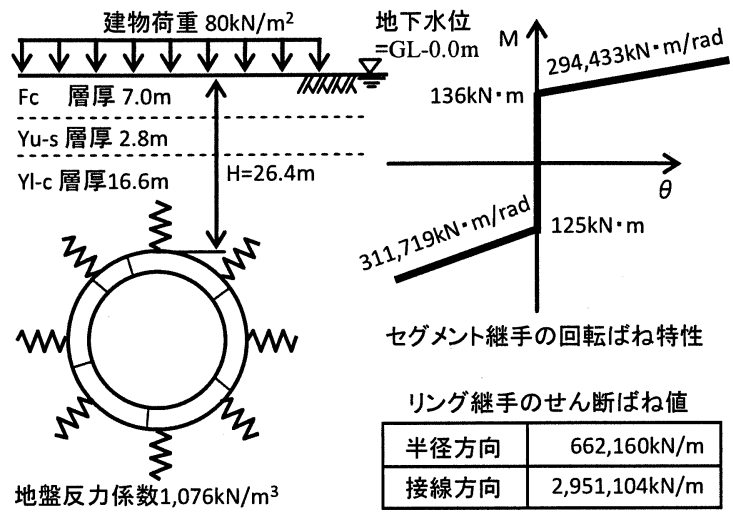

図-6設計条件と継手ばね特性

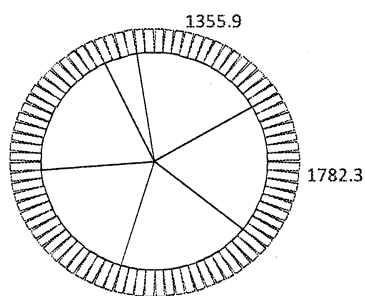

軸力(単位 : $\mathrm{kN}$ )

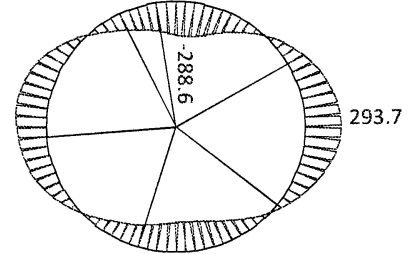

モーメント(単位 : $\mathrm{kN} \cdot \mathrm{m})$

図-7 断面力

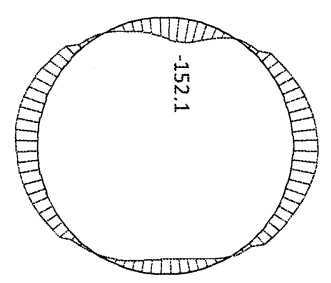

図-8 主枌の内空側鉄筋応力(単位 : $\mathrm{N} / \mathrm{mm}^{2}$ )

\section{(3) 現行設計}

鉄道構造物等設計標準シールド工法・同解説 ${ }^{16) （ 以 下 ， ~}$ シールド標準) に基づく「はりーばねモデル」による構 造計算法およびトンネル標準示方書シールド工法・同解 説 ${ }^{17}$ の鉄筋応力に基づくひび割れ幅の算定式を用いて, 当該トンネルのひび割れ幅を算定し，現行の設計法の適 用性を検証した.

セグメントの諸元は表-2に示した通りであり，その他 の設計条件およびシールド標準に準拠して算定した地盤 反力係数と継手のばね特性を図-6に示す．また，Yl-c層 のN值は1〜3程度であるため, 鉛直土圧は全土被り土圧 となる．なお，地下水位は当初設計の GL- $0.0 \mathrm{~m}$ とてい る.このため, 圧密による鉛直付加荷重および地下水位 上昇の影響は考慮しないものとした.

「はりーばねモデル」による計算結果から得られた断 面力を図-7に，引張鉄筋の応力度を図-8に示す。

鉄筋の許容応力度は $180 \mathrm{~N} / \mathrm{mm}^{2}$ であり, 許容応力度を 超過する応力は生じないが，(1)式に基づきひび割れ幅 
を算定すると，主枌の鉄筋応力が-152.1 $/ \mathrm{mm}^{2}$ の位置(天 端部)でひび割れ幅は0.18mmとなり，この程度のひび割 れが天端部内空側に分散することとなる.

$$
w=\ell_{\max }\left[\frac{\sigma_{s e}}{E_{s}}+\varepsilon_{c d}^{\prime}\right]
$$

ここに, $w$ : ひび割れ幅, $\ell_{\text {max }}$ : 配力鉄筋の最大間隔, $\sigma_{\mathrm{se}}$ : 鉄筋応力度の増加量 (ヤング係数比 15 として算 出）, Es : 鋼材のヤング係数, $\varepsilon^{\prime}{ }_{\text {odd }}$ : コンクリートの収 縮およびクリープ等によるひび割れ幅の増加を考慮する ための数值 $\left(=150 \times 10^{-6}{ }^{17}\right)$

この結果は，実トンネルにおける20年後のひび割れ発 生状況とは一致するものの, 建設当初にひび割れが生じ ていなかったことと一致していない. この相違は, 現行 設計では安全側の計算を前提としているために生じるも のであり, 維持管理で補修, 補強の意思決定を数值解析 で行う場合には, より精度の高い解析法や現行設計法の 修正が必要となることを示唆している.

\section{3. 再現解析法によるシミュレーション}

\section{（1）土水連成解析}

土水連成解析では, 前述した環境履歴のみを入力して, トンネル全周の変位分布を求めた.

解析手順としては，まず，地盤の自重解析を間隙水圧 が消散するまで行い原地盤を作成した. つぎに，シール ド掘削面を解放した後にトンネルを配置し，地下水位の

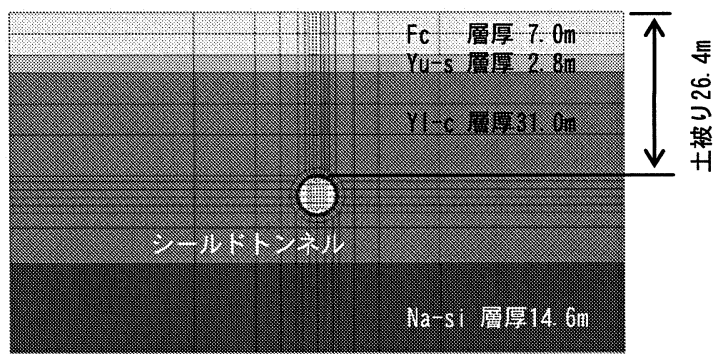

図-9 解析モデル（土水連成解析）

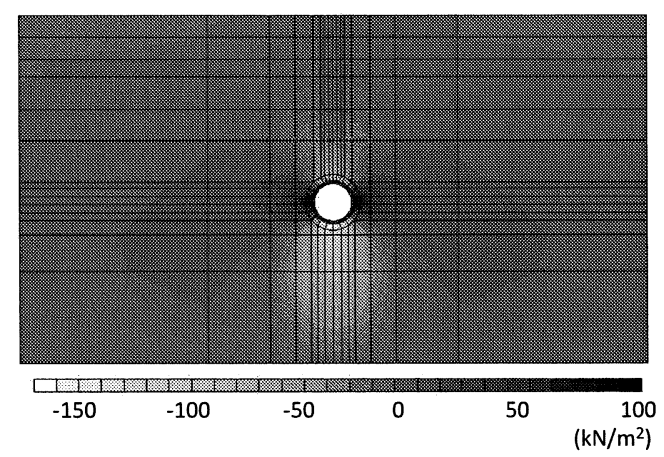

図-10 過剩間隙水圧（解放量100\%)
土木学会論文集F1 (トンネル工学), Vol. 67, No. 3, I_109-I_116, 2011.

影響として各ステップ毎にその期間相当の水位上昇量 （約 $0.3 \mathrm{~m} /$ 年）をYl-c層上面に等分布荷重で作用させた. なお，シールド掘削に伴う応力の解放程度は掘削面の節 点に線形ばねを配置して，このばね值を変更することで 調整した.

実際には前述した影響以外にも地上部の利用状況の変 化等による影響も存在した可能性があるが，これらの定 量的な記録が現存しないため,「シールド掘削による影 響」にこれらを含めることとした. そして，このシール ド掘削面の解放割合（掘削面で全て応力が解放されたと きに生じる変位量に対して節点ばね値を調整した変位量 の比率）をパラメータとして，解析結果と図-4の内空変 位の計測結果を比較した.

解析モデルは図-9に示す二次元場の弾性モデルを使用 しており, 地盤, トンネルの物性値は表-1, 表-2に示し た通りである．変位境界条件は，底面では鉛直方向の節 点変位を固定とし, 側面では水平方向を固定とした. 排 水境界条件は，側面とトンネル周面を非排水とした.

a) 過剩間隙水圧

図-10には，解放割合を100\%とした場合に，シールド 掘削時に発生した過剩間隙水圧を示す．掘削面の解放に より，スプリングライン付近では正の過剩間隙水圧，上 下端付近では負の過剩間隙水圧が生じることがわかる.

\section{b) 内空変位量}

図-11〜図-13は，解放割合が100\%，50\%，0\%となるよ うに掘削面の節点ばね值を設定したときの内空変位量の 経時変化を示したものであり, シールド掘削時の初期変 位量も含む内空変位量（各図中の(1)）と含まない内空変 位量（各図中の(2)）を示した.

図-10に示すシールド掘削時の過剩間隙水圧の影響お よびYl-c層上面に地下水位の上昇を考慮して作用させた 等分布荷重の影響により, 経過年数とともに変位が増加 している. これらの特徵として, 初期の解放割合が小さ いほうが，初期にトンネルに生じる変位量は大きくなり， その後の過剩間隙水圧により生じる変位量が小さくなる ことがわかる.

図-4の計測結果はシールド掘削時の初期変位量を含ま ない値であるため, 解析結果との比較対象は図-11〜図13の(2)の值であり, 解放割合100\%とすると計測結果と 比較的良い一致が見られた。

\section{(2) 非線形FEM}

土水連成解析から求まったトンネル全周の内空変位量 の鉛直成分を入力值として，非線形FEMによりひび割 れ・継手目開きの進展過程を求めた.

使用する解析モデルを図-14に示す。コンクリートは 非線形ソリッド要素，鉄筋は梁要素で個々にモデル化し た. また，コンクリートと鉄筋の付着，セグメント同士 


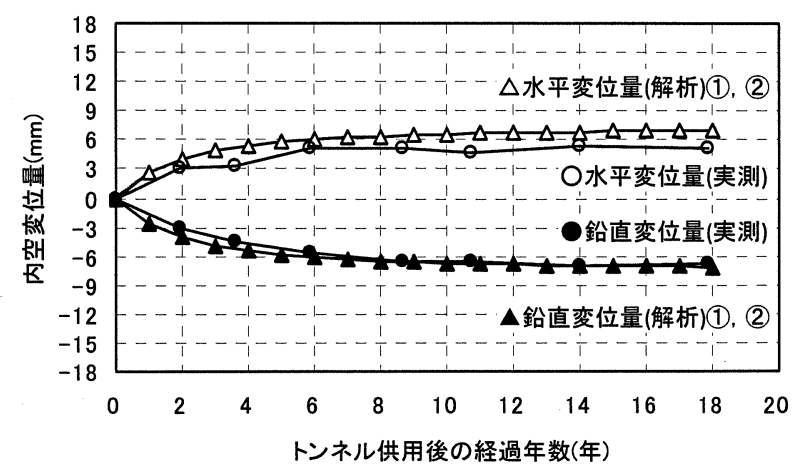

図-11 内空変位量の経時変化（解放割合100\%）

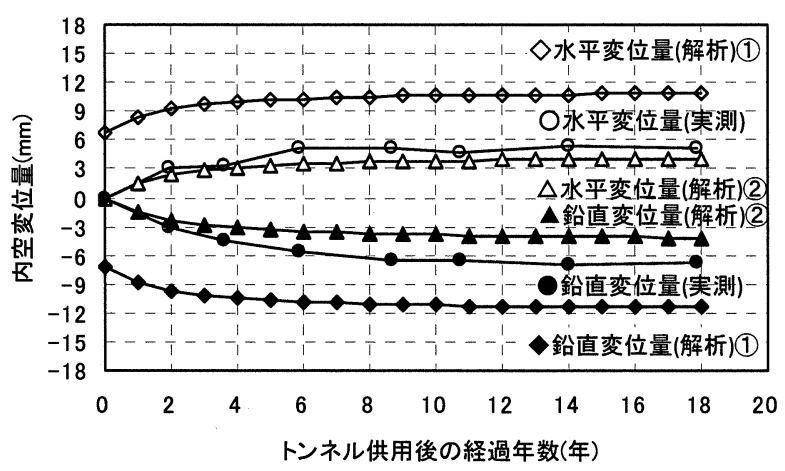

図-12 内空変位量の経時変化（解放割合 $50 \%$ )

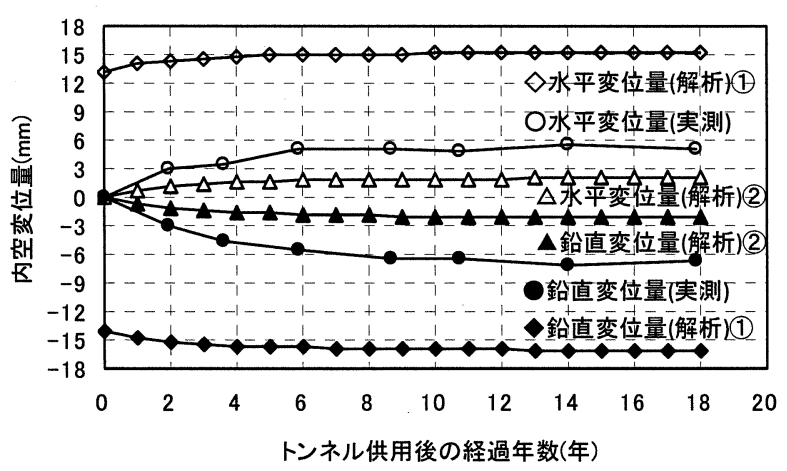

図-13 内空変位量の経時変化（解放割合 $0 \%$ )

の接触，継手ボルトにはばね要素を使用した．セグメン トの物性值は表-2に基づき設定した. また，セグメント 外周には地盤ばねを設置しており，ばね值はY1-c層の弾 性係数に基づき設定した.

コンクリート引張側は引張軟化係数 $E_{\mathrm{s}}^{18)}$ を導入し，ま た，圧縮側は降伏基準はモール・クーロン則に基づく完 全弾塑性とした. ひび割れは最大主応力が引張強度より 大きくなる箇所で同主応力発生方向の直角方向に発生す るものとし, 軟化後は応力はすぐにゼロとせず, 式(2) で定義する指数関数を用いた.

$$
E_{s}=c \cdot \sigma_{c r} \exp \left(-c\left(\varepsilon-\varepsilon_{c r}\right)\right.
$$

ここに, $E_{\mathrm{s}}$ : 引張軟化係数, $c$ : 残留特性係数, $\sigma_{\mathrm{a}}$ : ひ び割れ発生応力 $\left(=3.04 \mathrm{~N} / \mathrm{mm}^{2}{ }^{219}\right), \varepsilon:$ ひずみ, $\varepsilon_{\mathrm{\alpha}}$ :

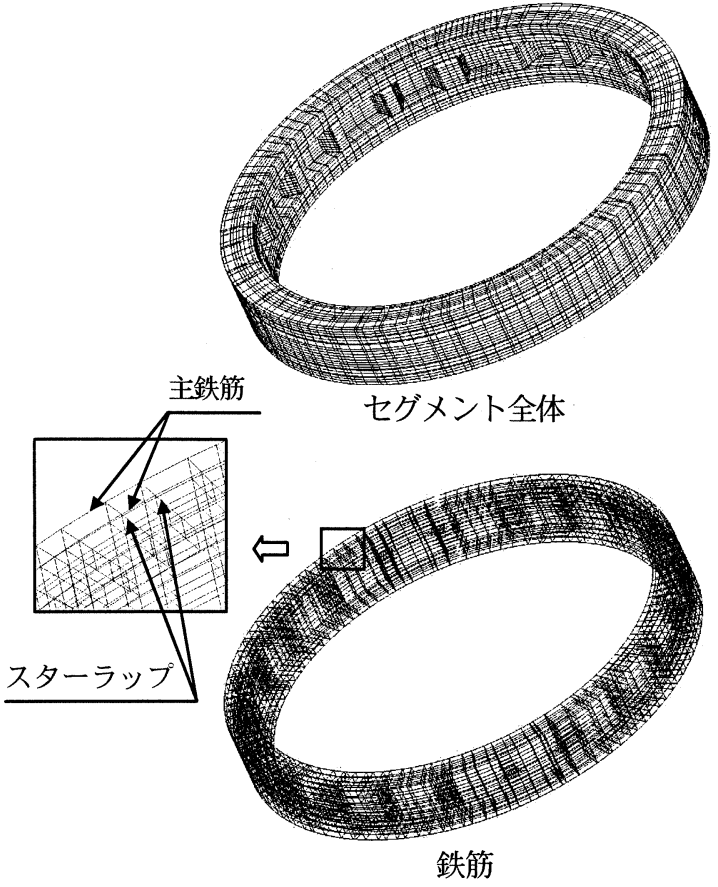

図-14 解析モデル（非線形FEM）

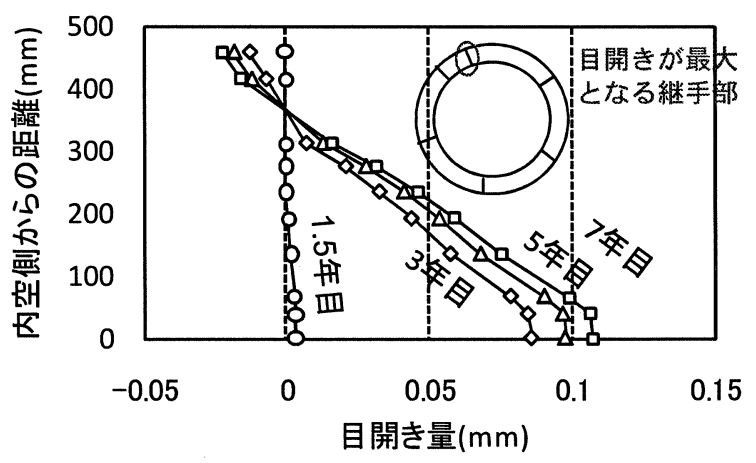

図-15 継手目開き量

ひび割れ発生ひずみ

a) 継手目開きの進展過程

継手目開きが最大となる位置の継手目開き量を図-15 に示す。継手目開き量は 3 年目に $0.1 \mathrm{~mm}$ 程度となるがそ れ以降の増加量は小さい. セグメント厚さ方向には内空 側から $350 \mathrm{~mm}$ 程度まで生じており，セグメントのひび割 れ深さよりも大きい. ただし，対象トンネルの継手部の シール材は2段であり，ぞれぞれ内空側から125mmの位 置および390mmの位置に配置されているため，地山側の シール材位置までの目開きは生じていない.

なお，継手ボルトが降伏応力に達した場合のボルトの 伸び量を求めると $0.47 \mathrm{~mm}$ 程度となり, 目開き量に応じ てボルトが伸びたとしても，図-15からわかるように十 分小さな値である.

\section{b)ひび割れの進展過程}

セグメントのクラックひずみ（ $\varepsilon-\varepsilon_{\mathrm{a}}:$ ひび割れを生 じるひずみ量からの増分）のコンター図を図-16に示す。 


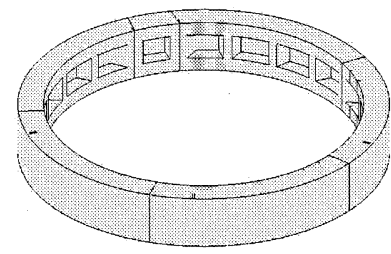

天端

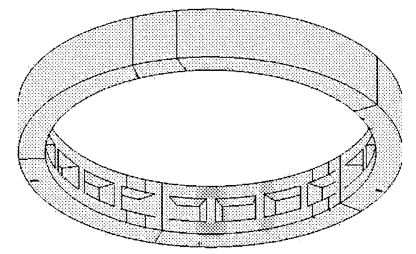

下端

1.5 年目

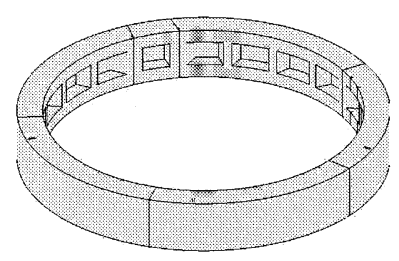

天端

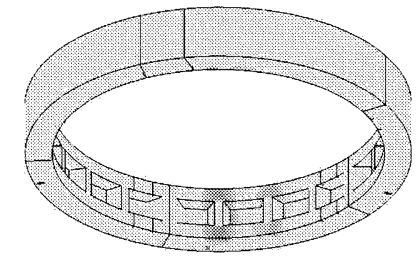

下端

2年目

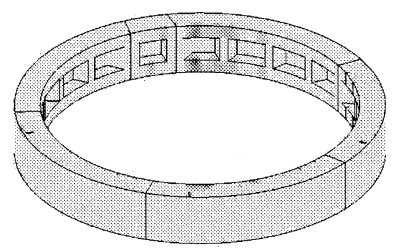

天端

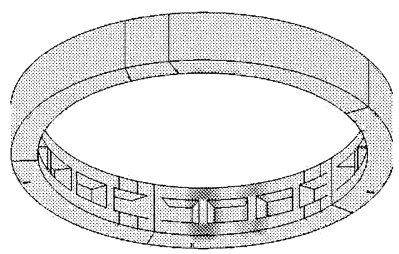

下端

3年目

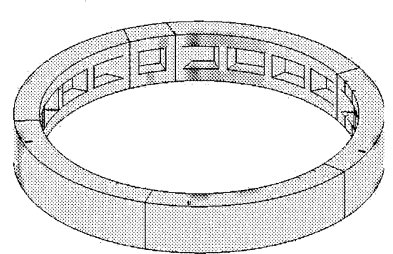

天端

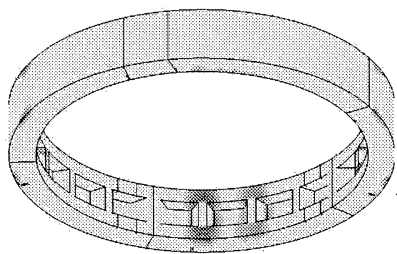

下端

5年目

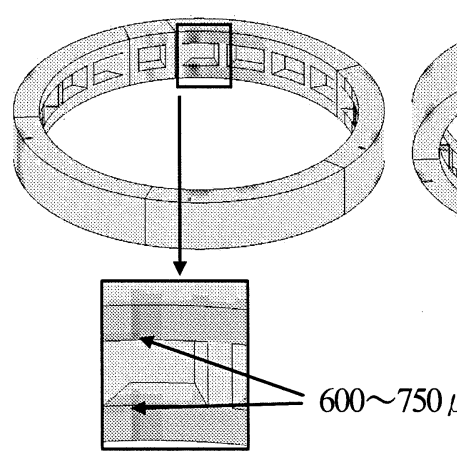

天端
下端

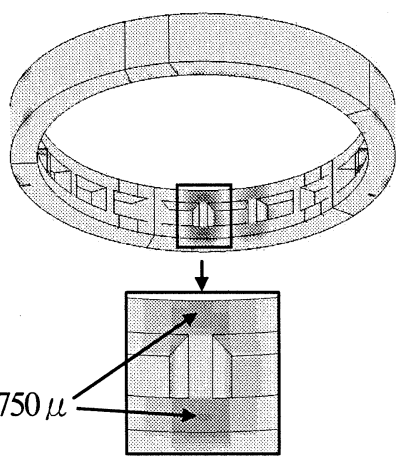

7年目
土木学会論文集F1 (トンネル工学), Vol. 67, No. 3, I_109-I_116, 2011.

図中, 最も薄い着色部はクラックひずみが0の箇所を示 し，これより濃い着色部が解析上のひび割れ発生位置を 示している.

セグメント内空側のひび割れは，1.5年目に天端内空 側の主桁と縦リブの接合部の四隅にひび割れが発生し, 2年目以降は同じ位置のひずみ量が増加するとともに主 桁全体に広がっていく. 以後, 7年目にかけて対象トン ネルで観察されたひび割れと同様に主桁全体に徐々に分 散する結果となる.このときのひび割れ深さは $200 \mathrm{~mm}$ 程 度である. なお, 下端内空側も同傾向にあり, 縦リブ付 近の主桁のクラックひずみが増加している.

また，セグメント背面側は，負曲げとなるスプリング ライン位置においてひび割れが生じるが，背板のクラッ クひずみが非常に小さいため, セグメントを貫通するも のではない.

\section{c)ひび割れ幅と継手目開き量の関係性}

内空側の主栴鉄筋応力を図-17に示す．鉄筋応力もク ラックひずみと同様の分布を描いており，1.5年目では 主桁と縦リブの接合部において局所的に大きい応力が生 じるが, その後は同一箇所の応力が大きくなりつつ, 周 囲に広がることがわかる.

この鉄筋応力から，現行設計法と同様に(1)式を用い て天端部の主桁と縦リブの接合部（1.5年目の最大鉄筋 応力の位置）のひび割れ幅を求めると図-18となる．な お，図-18には継手目開き量の内空側表面の值と現行設 計によるひび割れ幅を合わせて示す.

ひび割れ幅は1.5年目から増加しているが，3年目以降 に目開き量が増加するのに伴いひび割れ幅の増加量が小 さくなっていることがわかる. また, 対象トンネルでは, 圧密による影響を無視した現行設計法で計算された值は, 再現解析よりも大きい值を示していることがわかる.
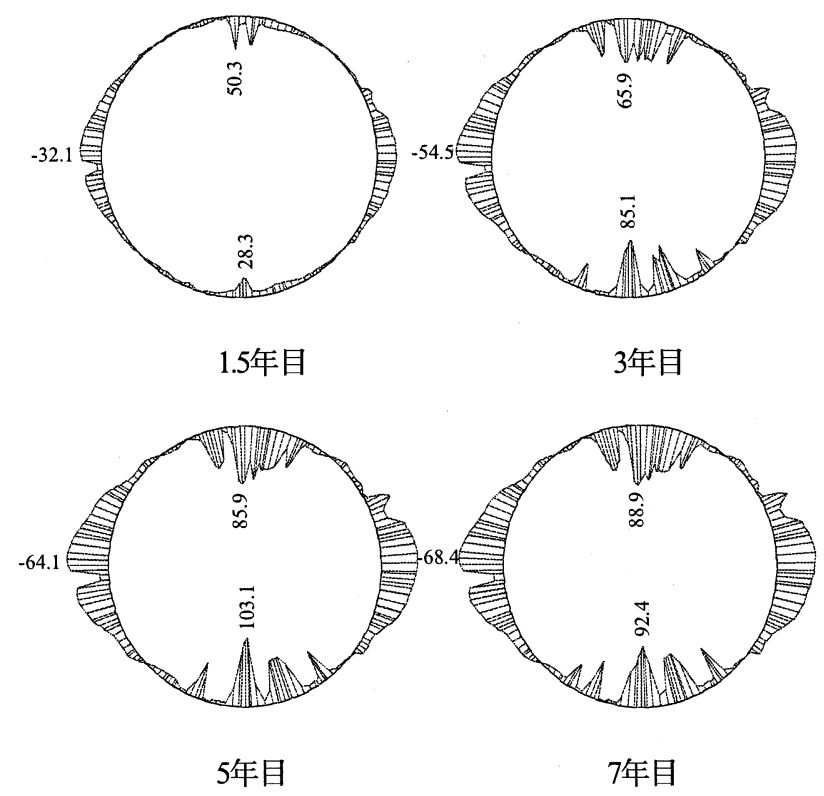

図-17 主桁の内空側鉄筋応力(単位 : N/mm²) 


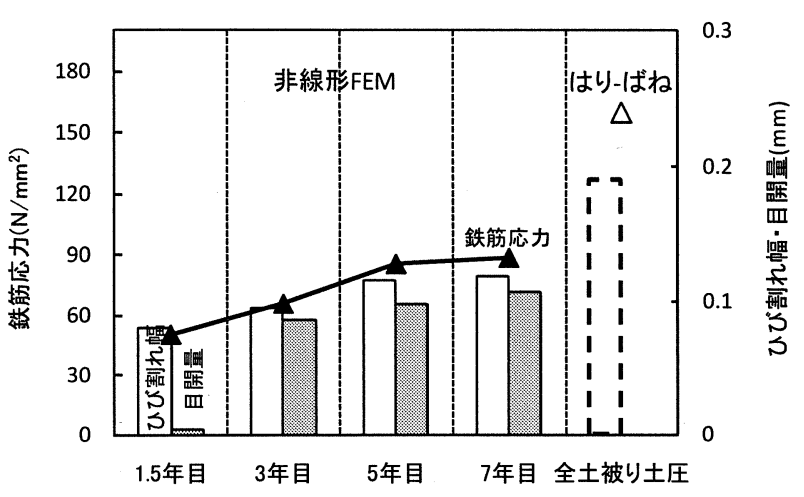

図-18 鉄筋応力, ひび割れ幅, 目開き量

\section{(3) 考察}

本研究で用いた再現解析法において，1.5年目にひび 割れは発生するものの, 局所的かつひび割れ幅が $0.1 \mathrm{~mm}$ を下回る程度ものであった．以後，7年目までに天端付 近に徐々に分散してひび割れが発生した. トンネルの内 空変位も7年目でほぼ安定しており, 実トンネルのひび 割れ発生傾向とよい一致をみることができた. また，再 現解析では，現場においても把握することが困難である 圧密のみに起因するひび割れ・継手目開きの進展過程を 定量評価することができた.

一方，現行の設計法は再現解析法よりも安全側の值を 示しているため, 安全側余裕をみた検討を実施するうえ では有効であると考えられる. ただし，正確な実トンネ ルのひび割れ発生位置やひび割れ幅等を表現するもので はなく, 縦リブ位置の配置や形状等によっては応力集中 の程度が大きくなることも想定されるため, 断面力の割 り増しが必要となる場合もあると考えられる.

以上の結果から, 再現解析法はこのようなひび割れ・ 継手目開きの進展過程を評価するうえで有効な手法であ るものと考える.

\section{4. まとめ}

供用後のシールドトンネルに生じるひび割れ・継手目 開きを再現できる数值解析法を構築し, 中子形セグメン トを使用した実トンネルのシミュレーションを通して, その適用性を検証した. その結果, 得られた知見は以下 のとおりである.

1) シールドトンネルが経験した環境履歴を入力する再現 解析手法を構築して，実トンネルのシミュレーションを 実施した結果，許容応力度法を軸とした現状の設計計算 法では困難であった内空変位量，ひび割れ発生状況を現 状を再現することができ，これらの進展過程を評価する うえで有効な手法であることを示した.
土木学会論文集F1 (トンネル工学), Vol. 67, No. 3, I_109-I_116, 2011.

2) 再現解析法では，まず，トンネル全周の内空変位を求 めるために土水連成解析を実施した. この結果, 初期の 解放量が小さいほうが, 初期にトンネルに生じる変位量 は大きくなり，逆に，その後の過剩間隙水圧により生じ る変位量は小さくなることが確認された.

3) 再現解析法では, ひび割れ・継手目開き量の進展過程 を求めるため, 土水連成解析から求めたトンネル全周の 内空変位を入力値とする非線形FEMを実施した. この結 果, 中子形セグメントの場合には内空側の主桁部にひび 割れが集中すること, その進展過程は内空変位量が小さ いレベルでは縦リブが寄与して接合部に生じ, 変位量の 増加とともにその影響は小さくなり，全体に分散するこ とがわかった.

4) 非線形FEMから求めるひび割れ幅と継手目開き量の進 展を比較した結果，ひび割れは1.5年目から増加するが, 継手目開き量が増加していくに伴いひび割れの増加量が 小さくなる傾向を示すことを確認した. 一方，継手目開 き量は1.5年目ではほぼ発生しないものの，3年目以降か ら増加していく傾向を示すことを確認した.

5) 現行の設計法は再現解析法よりも安全側の値を示して いるため, 安全側余裕をみた検討を実施するうえでは有 効であると考えられる. ただし，正確な実トンネルのひ び割れ発生位置やひび割れ幅等を表現するものではなく, 縦リブ位置の配置や形状等によっては応力集中の程度が 大きくなることも想定されるため, 断面力の割り増しが 必要となる場合もあると考えられる.

今後は, より詳細な環境履歴を考慮できる解析手法を 開発していくとともに，鉄筋腐食による耐力低下等も考 慮して, 維持管理段階におけるシールドトンネルの適切 かつ合理的な健全度評価法や本手法を用いた劣化予測手 法の開発等, 維持管理の実務に反映できるような研究を 進めたい.

\section{謝辞：}

本研究の「土水連成解析」を進めるにあたり, 千葉工 業大学 小宮教授, 高橋氏に多大なるご協力をいただい た. また,「非線形FEM」を進めるにあたり, 同済大学 の杜教授に多大なるご協力をいただいた．ここに感謝の 意を表する.

\section{参考文献}

1) 財団法人 鉄道総合技術研究所: 鉄道構造物等維持管 理標準・同解説(構造物編 トンネル), 丸善, 2007.

2) 斎藤正幸, 古田勝, 山本稔: 沖積層地盤に構筑した シールドトンネルの変形に関する考察, トンネル工 学研究発表会論文・報告集第 4 巻, pp55-62, 1994.

3) 有泉毅, 五十嵐寛昌, 金子俊輔, 永谷英基, 山崎剛, 日下部治 : 周辺地盤の圧密沈下に伴う既設シールド 
トンネル作用荷重の変化メカニズム, 土木学会論文 集 No.750/III-65, pp115-134，2003.

4) 津野究, 三浦孝智, 石川幸宏, 山本努, 河畑充弘 : 内空断面測定および変状展開図より把握したシール ドトンネルの変形傾向, トンネル工学報告集第 17 巻, pp.257-261, 2007.

5) JTA 保守管理委員会 : 連載講座 建設・保守管理へ のフィードバック(3), トンネルと地下第 29 巻 7 号, pp75-84, 土木工学社, 1998.

6) 財団法人日本鉄道施設協会 : シールドトンネルの設 計施工指針（案）, pp97-99，1983.

7) Marston,A. and A.O. : The theory of loads on pipe in ditches and tests of cement and clay drain tile and sewer pipe, Bulletin 31, Iowa Eng. Experiment Station, 1913.

8) Spangler,M.G. : Underground conduits - An appraisal of modem research, Transactions of ASCE, Paper No.2337, Vol.113, pp316-374, 1948.

9) 小山幸則, 米島賢二, 松本吉雄, 新井泰 : 自然地盤 沈下に伴うトンネルへの増加荷重の検討, 第 29 回土 質工学研究発表会, pp1995-1996, 1994.

10）赤木寛一，小宮一仁：軟弱粘性土地盤の沈下に伴う トンネル周面土圧の変化について, 第 25 回土質工学 研究発表会, pp1747-1750, 1990.

11）赤木寛一，小宮一仁，尾浦猛人：粘土地盤の圧密沈 下に起因するトンネル土圧の作用機構について，第
29 回土質工学研究発表会, pp1993-1994, 1994.

12）有泉毅，金子俊輔，塩冶幸男，山崎剛，日下部治 : 軟弱粘性土地盤の圧密に伴うシールドトンネルの長 期荷重に関する解析的研究, 土木学会論文集 No.799/ III-72, pp89-108, 2005.

13) 新井泰, 杜世開, 山本努, 渡辺忠朋 : 非線形挙動を 考慮した開削トンネルのひび割れ調査結果シミュレ ーション, トンネル工学論文集第 15 巻, pp173-181, 2005.

14）東京都土木技術研究所：東京都土木技術研究所年報, 1972 2005

15）東京都土木技術センター：土木技術センター年報, 2006 2007

16）財団法人 鉄道総合技術研究所：鉄道構造物等設計標 準・同解説 シールドトンネル，丸善，2003.

17) 社団法人 土木学会 : トンネル標準示方書 シールド工 法・同解説, 2006 .

18）吉川弘道，西藤厚，金刀督純 : 引張強度の空間的変 動を考慮したコンクリートの FEM 破壊シミュレーシ ヨン, コンクリート工学論文集 第 7 巻第 2 号, pp103-117, 1996.

19) 財団法人 鉄道総合技術研究所: 鉄道構造物等設計標 準・同解説 コンクリート構造物，丸善，2004。

(2011.6.6 受付)

\section{NUMERICAL STUDY ON CRACK PROPAGATION IN SEGMENT OF SHIELD TUNNEL}

\section{Shinji YAKITA, Takashi NAKAYAMA, Shinji KONISHI and Hirokazu AKAGI}

Long-term consolidation of surrounding ground may cause deformation, cracks of segment, opening of joints and other faults in shield tunnels located in soft clayey soil. To distinguish the cracks and opening caused by consolidation from those caused by another reason, such as construction method, it is required to develop the calculation method considering the progress of cracks and opening in accordance with the time-history stress and strain experienced by the shield tunnels. This paper proposes the calculation method, coupling the ground-tunnel interaction analysis and the sophisticated tunnel deformation analysis. 